\title{
Pengaruh kualitas daya tarik wisata budaya terhadap minat kunjungan wisatawan nusantara ke kotagede
}

\author{
Syariful Anhar Harahap ${ }^{1)}$, Dwita Hadi Rahmi ${ }^{2)}$ \\ Mahas is wa Magister Arsitektur \& Perencanaan Pariwisata, Universitas Gadjah Mada ${ }^{1)}$ \\ Jl. Nologaten, Sleman, Yogyakarta, Telp: 082275518759 \\ Dosen Magister Arsitektur \& Perencanaan Pariwisata, Fakultas Teknik, Universitas Gadjah Mada ${ }^{2)}$ \\ Email: anharhrp04@gmail.com ${ }^{1)}$
}

\begin{abstract}
Abstrak
Daya tarik wisata budaya Kotagede berupa bangunan arsitektur memiliki nilai keberagaman dan keunikan yang sangat tinggi. Hal tersebut diy akini dapat memicu minat wisatawan nus antara untuk berkunjung akan tetapi secara kualitas daya tarik wis ata buday a Kotagede masih memilikipermasalahan dalam hal aksesibilitas dan kelengkapan fasilitas umum dan pariwisata dalam menunjang aktivitas wis atawan. Penelitian ini bertujuan untuk mengetahui kualitas daya tarik wis ata budayaKotagede, minat kunjungan wisatawan nusantara ke Kotagede dan pengaruh ke dua variabel tersebut. Dengan menggunakan metode penelitian kuantitatif dan hasil akan dianalis is menggunakan statistik deskiptif dan statistik inferensial. Hasil penelitian terhadap pengaruh kualitas daya tarik wis ata budayadanminat kunjung an wisatawan nus antara ke Kotagede yaitu:(1) daya tarik wis ata budaya Kotagedememilikinilai yang baik dan yang menjadi daya tarik utama wis ata budaya Kotaged e adalah keunikan daribangunan arsitektur dan keunikan kawas an Kotagede, (2) minat kunjung an wisatawan nusantara ke Kotagede sangat tinggi dan keunikan bangunan arsitektur serta kemudahan menjangkau Kotagedemenjadifaktor utama wis atawan nus antara untuk mengujungi Kotagede, (3) berdasarhasiluji person productmoment dan uji $t$-test maka diperoleh nilai $\mathrm{r}_{\text {hitung }} 0,540>\mathrm{r}_{\text {tabel }} 0,195$ dan nilai $t$-test $\mathrm{t}_{\text {hitung }} 6,356>\mathrm{t}_{\text {tabel }} 1,661$ maka dapat dinyatakan bahwa pengaruh antara kualitas daya tarik wis ata budaya terhadap minat kunjungan wis atawan nusantara sebesar 0,540 adalah signifikan digeneralis as ikan untuk populasidimanadiambil (Ho: tidak ada hubungan di tolak).
\end{abstract}

Kata kunci: Kualitas, Daya tarik wisata budaya, Minat kunjungan, Wisatawan Nusantara

\begin{abstract}
Kotagede's cultural tourist attraction in the form of architectural buildings has a very high valueof diversity and uniqueness. This is believed to trigger the interest of domestic touriststovisit,butinterms of quality, Kotagede's cultural tourist attraction still has problems in terms of accessibility and completeness of public facilities and tourism in supporting tourist activities. Thisstudyaimstodetermine the quality of Kotagede's cultural tourist attraction, interest in visiting IndonesiantouriststoKotagede and the influence of these two variables. By using quantitative research methods and results willbe analyzed using descriptive statistics and inferential statistics. The results ofthestudyontheinfluence of the quality of cultural tourist attraction and interest in visiting domestic tourists to Kotagedeare:(1) Kotagede cultural tourist attraction has good value and the mainattractionofKotagedeculturaltourism is the uniqueness of the architectural building and the uniqueness of the Kotagedearea,(2)theinterest of domestic tourist visits to Kotagede is very high and the uniqueness of architecturalbuildingsandthe ease ofreaching Kotagede are the main factors of domestic tourists visiting Kotagede,(3)basedonthe results of the person product moment and t-test, the value of $0.540>$ r table 0.195 and thevalueoft-test t-count $6.356>$ t table 1,661, it can be stated that the influence of the qualityofculturaltouristattraction on the interest ofdomestic tourists of 0.540 is significantly generalized to thepopulationtaken(Ho:no relationship rejected).
\end{abstract}

Keywords: Quality, cultural tourist attraction, interest in visits, domestic tourists

\section{PENDAhuluan}

Daya tarik wisata merupakan faktor penting bagi destinasi dalam mendatangkan wisatawan. Hal ini dikarenakan unsur-unsur yang terdapat dalam daya tarik wisata yang meliputi orisinalitas, keberagaman, scarity (kelangkaan) dan keutuhan daya tarik wisata mampu mempengaruhi minat kunjungan wisataw an (Marhendi, 2005:9). Bagi Kotagede sendiri, daya tarik wisata budaya merupakan unsur utama dari kegiatan wisata di Kotagede. Hal ini dikarenakan sebagian besar aktivitas wisata di Kotagede berhubungan langsung dengan daya 
tarik wisata budaya yang ada. Jika dilihat berdasarkan jumlah kunjungan maka daya tarik wisata budaya merupakan penyumbang terbesar wisatawan yang berkunjung ke Kotagede. Berdasarkan data Statistik Kepariwisataan Daerah Istimewa Yogyakarta (DIY) tahun 2016 tercatat bahw a 5.429 wisatawan yang berkunjung ke Kotagede semuanya melakukan aktivitas wisata di daya tarik wisata budaya Kotagede yaitu di kawasan masjid dan kompleks raja-raja Mataram Kotagede.

Untuk itu, agar keberadaan destinasi wisata Kotagede dapat terus bersaing dalam mendatangkan wisatawan maka diperlukan daya tarik wisata budaya yang berkualitas yang akan berfungsi sebagai pembeda dengan destinasi wisata lainnya. Keberadaan unsur-unsur kualitas daya tarik wisata budaya yang meliputi (1) keunikan dan keberagaman daya tarik wisata (2) kelengkapan informasi (3) fasilitas umum dan pariw isata yang memadai (3) jaringan aksesibilitas (4) sumber daya manusia (5) pelayanan dan (6) kebersihan akan mampu memberikan informasi yang lengkap tentang sebuah destinasi (Poerwanto, 2004) akan memudahkan wisataw an dalam menentukan destinasi yang akan dituju.

Secara daya tarik wisata, unsur-unsur yang terdapat dalam daya tarik wisata budaya Kotagede dapat dikatakan masih terpelihara dengan baik. Akan tetapi, jika dilihat berdasarkan unsurunsur kualitasnya, maka daya tarik wisata budaya Kotagede masih perlu untuk diperhatikan. Berdasarkan observasi yang dilakukan oleh peneliti didukung dengan data dari hasil penelitian terdahulu maka daya tarik wisata budaya Kotegede secara kualitas masih memiliki beberapa permasalahan, antara lain: (1) keberadaan daya tarik wisata budaya yang tersebar di wilayah Kotagede sangat menyulitkan wisatawan untuk mengujunginya hal ini dikarenakan sebaran daya tarik wisata budaya tersebut tidak didukung dengan informasi yang lengkap terkait lokasi daya tarik wisata budaya yang ada (2) keberadaan daya tarik wisata budaya Kotagede belum didukung dengan sarana dan prasarana yang memadai seperti lahan parkir yang kurang memadai, dan (3) terkait dengan minat kunjungan, adanya fenomena yang menunjukkan bahwa semakin tua usia wisatawan maka jumlah pengunjung dan intensitas kunjungan ke Kotagede semakin menurun.

Permasalahan-permasalahan di atas juga diperkuat dengan hasil penelitian yang dilakukan oleh Octaviano (2013: 100) dalam tesisnya yang berjudul "Kualitas Produk Wisata Arsitektural di Kawasan Kotagede, Yogyakarta". Penelitian yang dilakukan oleh Adhelia, Ahjono dan Yudana (2015) dengan judul "Keterpaduan Komponen Pengembangan Pariw isata Kotagede Sebagai Kawasan Wisata Budaya Berkelanjutan” juga memperlihatkan adanya permasalahan terhadap aksesibilitas dalam kemudahan pencapaian jarak dari/ ke daya tarik wisata dengan moda transportasi terdekat. Komponen tersebut dianggap belum mampu mendukung berjalannya kegiatan wisata secara optimal karena pencapaiannya yang sulit. Dengan demikian, fakta-fakta tersebutlah yang menjadi dasar bagi peneliti untuk melakukan penelitian terkait "Pengaruh Kualitas Daya Tarik Wisata Budaya Terhadap Minat Kunjungan Wisataw an Nusantara Ke Kotagede". Dengan penelitian bertujuan untuk mengetahui kualitas daya tarik wisata budaya Kotagede, mengetahui minat kunjungan wisatawan nusantara ke Kotagede dan mengetahui pengaruh kualitas daya tarik wisata budaya terhadap minat kunjungan wisatawan nusantara ke Kotagede.

\section{METODE PENELITIAN}

Penelitian ini dilakukan di Kotagede dengan lokasi penelitian difokuskan pada kelurahan Prenggan, keluruahan Purbayan dan kelurahan Jagalan dengan alasan daya tarik wisata budaya Kotagede lebih banyak pada daerah ini. Penelitian ini menggunakan jenis penelitian kuantitatif dengan teknik pengumpulan data dilakukan berdasarkan dua jenis data, yaitu: (1) data primer dilakukan dengan cara observasi dan kuesioner. Observasi dilakukan untuk memperoleh data terkait: (a) permasalahan kualitas daya tarik w isata budaya Kotagede yang meliputi (1) lokasi sebaran daya tarik w isata budaya di Kotagede (2) keberadaan fasilitas umum dan pariw isata Kotagede (b) terkait minat kunjungan w is ataw an, adanya fenomena yang menunjukkan penurunan jumlah dan intensitas kunjungan ke Kotagede berdasarkan usia wisatawan. (2) Data sekunder diperoleh melalui dokumentasi terkait dengan peta-peta tematik kawasan dan perkembangan jumlah kunjungan wisatawan. 


\section{Populasi dan Sampel}

Berdasarkan data Statistik Kepariwisataan Daerah Istimewa Yogyakarta (DIY) Tahun 2016 jumlah kunjungan wisataw an nusantara ke Kotagede sebanyak 5.418 w isataw an. Jumlah tersebut dinyatakan sebagai populasi dari kunjungan wisatawan nusantara ke Kotagede. Rumus penentuan sampel sebagai berikut:

$$
\mathbf{n}=\frac{\mathrm{N}}{1+\mathrm{N}(\mathrm{e})^{2}}
$$

Keterangan:

$\mathrm{n}$ : Ukuran sampel yang dibutuhkan

$\mathrm{N}$ : Jumlah Populasi

e : Margin error yang diperkenan (5-10\%)

Berdasarkan rumus di atas dan mengacu pada jumlah kunjungan wisatawan (populasi) pada tahun 2016 sebanyak 5.418 wisatawan, maka hasil yang di dapat untuk ukuran sampel adalah sebanyak 98.19 w isataw an dengan margin error sebesar $10 \%$ untuk itu penelitian menetapkan jumlah sampel sebanyak $100 \mathrm{w}$ isatawan nusantara.

Tabel 1. Variabel Penelitian

Variabel

Kualitas Daya Tarik Wisata Budaya (X)

Minat Kunjungan Wisataw an Nusantara (Y)

\section{Indik ator}

1. Atraksi Wisata (keunikan dan keragaman)

2. Aksesibilitas (kondisi jalan, moda transportasi dan waktu tempuh)

3. Fasilitas (ketersediaan terkait fasilitas umum dan pariwisata)

1. Faktor Penarik (daya tarik wisata, aksesibilitas, informasi dan fasilitas

2. Faktor Pendorong (waktu, biaya dan alasan melakukan perjalanan)

\section{Parameter Instrumen}

\section{Skala Likert Kuesioner}

Skala Likert Kuesioner

Untuk analisis data, peneliti menggunakan dua teknik analisis data yaitu:(1) statistik deskriptif dan (2) statistik inferensial. Statistik deskriptif digunakan oleh peneliti untuk kepentingan analisis data dalam menjaw ab dua pertanyaan penelitian yang bersifat kualitatif. Statistik inferensial, yaitu teknik analisis data yang digunakan oleh peneliti dengan menekankan penggunaan metode statistik untuk mencari jaw aban terhadap permasalahan yang akan diteliti guna membuktikan hipotesis.

\section{HASIL DAN PEMBAHASAN}

\section{Profil Wisatawan}

Sebelum membahas kualitas daya tarik wisata budaya dan minat kunjungan wisatawan nusantara ke Kotagede terlebih dahulu penulis akan menuliskan profil wisatawan 
yang menjadi responden dalam penelitian ini. Hal ini bertujuan untuk memudahkan pembaca dalam memahami pembahasan terkait dua variabel tersebut.

Tabel2. Profil Wis atawan Nusantara Kotagede

Variabel Demografis Variabel Psikografis

$\begin{array}{lcccccccc}\text { No } & \begin{array}{c}\text { Jenis } \\ \text { Kelamin }\end{array} & \text { Jml } & \begin{array}{c}\text { Usia/ } \\ \text { Tahun }\end{array} & \text { Jml } & \text { Pekerjaan } & \text { Jml } & \text { Motif Kunjungan } & \text { Jml } \\ 1 & \text { Perempuan } & 69 & 18-25 & 74 & \text { Mahasiswa } & 74 & \text { Rekreasi } & 80 \\ 2 & \text { Laki-laki } & 31 & 26-30 & 14 & \begin{array}{c}\text { Pegawai } \\ \text { Swasta }\end{array} & 15 & \text { Penelitian } & 10 \\ & & 31-50 & 6 & \text { lainnya } & 6 & \text { Ziarah } & 9 \\ & & 13-17 & 3 & \text { Wiraswasta } & 5 & \text { lainnya } & 1 \\ & & & 100 & & 100 & & 100\end{array}$

Sumber: Hasil Penelitian, 2019

Berdasarkan tabel 2. di atas maka wisatawan nusantara Kotagede dapat di kelompokkan sebagai berikut:

1. Wisatawan Nusantara Kotagede Usia 18-25 Tahun

Kelompok wisatawan ini didominasi oleh mahasiswa, perjalanan wisata ke Kotagede dilakukan untuk tujuan rekreasi dengan menggunakan kendaraan pribadi yang dilakukan bersama teman pada siang (13.00-16.00 wib) dan sore hari (16.00-18.00 wib). Wisatawan ini membentuk kelompok dengan jumlah 1-10 orang dalam berkunjung, informasi wisata diperoleh melalui informasi lisan dan media elektronik.

2. Wisatawan Nusantara Kotagede Usia 26-30 tahun

Kelompok wisatawan ini merupakan sarjana yang telah bekerja sebagai pegawai swasta dan wirasw asta dengan tingkat pendapatan yang berdeda-beda. Kunjungan wisatake Kotagede dilakukan untuk tujuan rekreasi dengan menggunakan kendaraan pribadi. Perbedaan dengan kelompok sebelumnya ialah terkait dengan waktu kunjungan yaitu dilakukan pada siang hari.

3. Wisatawan Nusantara Kotagede Usia 30-50 Tahun

Perbedaan kelompok wisatawan ini dengan dua kelompok sebelumnya terletak pada motif kunjungan. Pertambahan usia wisatawan menunjukkan adanya perubahan motif kunjungan dari rekreasi untuk memenuhi kebutuhan fisik menuju kebutuhan batin yaitu untuk ziarah/ritual. Jenis kunjungan juga menunjukkan adanya perbedaan, dua kelompok wisatawan sebelumnya melakukan kunjungan bersama dengan teman akan tetapi w isatawan pada kelompok ini melakukan kunjungan wisata bersama keluarga.

\section{Kualitas Daya Tarik Budaya Kotagede}

Penilaian terhadap kualitas daya tarik wisata budaya Kotagede didasarkan pada kelompok wisatawan yang telah diuraikan di atas. Adapun tujuannya adalah untuk mendapatkan gambaran yang lebih rinci terkait kualitas daya tarik wisata budaya Kotagede berdasarkan segmentasi wisataw an tersebut. Dengan demikian, diharapkan pengembangan daya tarik wisata budaya Kotagede dapat berorientasi pasar dan produk. 
Tabel3. Skor Kualitas Daya Tarik Wis ata Budaya Kotagede

Indikator

Tot. Skor

\begin{tabular}{ccccccccc} 
& STS & TS & RR & S & ST & & \\
1 & 2 & 3 & 4 & 5 & 6 & 7 & 8 & 9 \\
Tot. Skor & 7 & 16 & 159 & 1580 & 1185 & 2947 & 7 & 100 \\
\multicolumn{7}{c}{ Aksesibilitas } \\
Tot. Skor & 8 & 102 & 498 & 1820 & 600 & 3028 & 8 & 100
\end{tabular}

Fasilitas
$\mathrm{Jml}$

Res. $\begin{array}{ccc} & \text { Jml Skor/ } \\ \text { Atraksi Wisata } & \text { Iteml Item }\end{array}$
100

100

$\begin{array}{lllllllll}\text { Tot. Skor } & 14 & 126 & 522 & 1144 & 315 & 2121 & 6 & 100\end{array}$

Jumlah total skor : $2947+3028+2121=8096$

Sumber: HasilPenelitian, 2019

Berdasarkan tabel 3. di atas diketahui bahwa kualitas daya tarik wisata budaya Kotagede yaitu jumlah skor ideal (kriterium) untuk seluruh item $=5$ x 21 x $100=10.500$ (jika semua menjawab SS). Jumlah skor yang diperoleh dari penelitian $=8.096$. Dengan demikian, tingkat persetujuan terhadap kualitas daya tarik wisata budaya Kotagede $=(8.096: 10.500) \mathrm{x}$ $100 \%=77,01 \%$ dari yang diharapkan $(100 \%)$. Secara kontinum dapat digambarkan sebagai berikut:

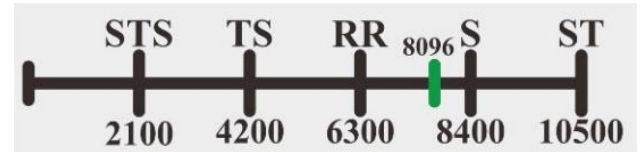

Gambar 1. Skor Kualitas Daya Tarik Wis ata Budaya Kotagede

Berdasarkan gambar 1. di atas data yang peroleh dari 100 responden maka rata-rata 8096 terletak pada daerah setuju. Dengan demikian, kualitas daya tarik wisata budaya Kotagede dapat dikatakan dalam kondisi baik (keterangan, gambar 1. diperoleh dari: (1) $1 \times 21 \times 100=$

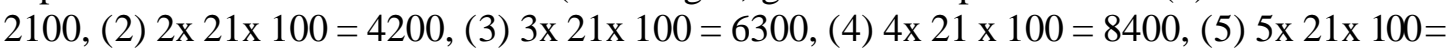
10500 dan $21=$ butir item pernyataan, $100=$ jumlah responden). Untuk melihat lebih jauh penilaian terhadap kualitas daya tarik wisata budaya Kotagede, maka tabel 3. di atas akan diuraikan berdasarkan indikatornya dengan tujuan untuk mendapatkan penilaian yang lebih rinci terhadap indikator tersebut yang nantinya dapat digunakan sebagai bahan evaluasi terhadap perencanaan pariw isata Kotagede.

Tabel4. Skor Kualitas Daya Tarik Wisata Budaya Kotagede

\begin{tabular}{lccccccc}
\multicolumn{2}{c}{ (Skala $1=$ Negatif, $2=$ agak negatif, $3=$ cukup, $4=$ positif, $5=$ sangat positif) } \\
No & Indikator & \multicolumn{5}{c}{ Penilaian } \\
& & STS & TS & RR & S & SS & Skala \\
$\mathbf{1}$ & $\mathbf{2}$ & $\mathbf{3}$ & $\mathbf{4}$ & $\mathbf{5}$ & $\mathbf{6}$ & $\mathbf{7}$ & $\mathbf{8}$
\end{tabular}

wisataw an nusantara Kotagede dengan usia 18-25 tahun

$\begin{array}{llllllll}1 & \text { atraksiwisata } & - & 0,06 & 1,40 & 42,61 & 31,92 & \mathbf{4 , 3 3} \\ 2 & \text { aksesibilitas } & - & 0,85 & 10,59 & 50,27 & 14,29 & \mathbf{3 , 9 3}\end{array}$


fasilitas (umum dan pariwisata)

$$
0,09 \quad 1,74 \quad 18,77 \quad 45,12 \quad 10,27
$$

b. wisatawan nusantara Kotagede dengan usia 26-30 tahun

1 atraksi wisata

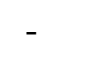

5,32

4,01

2 aksesibilitas

$-\quad 1,21$

, 21

4,75

$4,83 \quad 4,20$

3,55

3

fasilitas (umum dan

pariwisata)

$$
0,05 \quad 3,11 \quad 3,84 \quad 4,15 \quad 3,82
$$

c. wisatawan nusantara Kotagede dengan usia 31-50 tahun

2 aksesibilitas

$$
0,34 \quad 0,24
$$

fasilitas (umum dan pariwisata)

Indikator atraksi wisata mendapat penilaian positif dari tiga kelompok wisatawan tersebut. Hal ini disebabkan motif kunjungan wisatawan lebih didominasi oleh motif rekreasi sehingga terpenuhinya unsur fisik dalam berwisata maka tujuan berwisata juga sudah terpenuhi. Indikator aksesibilitas mendapat penilaian yang berbeda dari kelompok wisataw an di atas. Skor terendah terhadap indikator aksesibilitas diberikan oleh kelompok wisataw an usia 26-30 tahun dan skor tertinggi diberikan oleh kelompok wisatawan usia 31-50 tahun. Perbedaan tersebut disebabkan oleh faktor pekerjaan dan waktu berkunjung w is ataw an. Kunjungan w is ataw an usia 26-30 tahun yang dilakukan di akhir pekan menyebabkan kondisi jalan menuju Kotagede cukup padat sehingga kawasan Kotagede lebih sulit dijangkau. Sedangkan wisataw an usia 31-50 tahun memberikan skor cukup tinggi terhadap indikator aksesibilitas disebabkan waktu berkunjung wisatawan tersebut dilakukan di luar hari libur (kamis dan jumat) dan siang hari sehingga kondisi jalan menuju Kotagede cukup lancar dan menyebabkan kawasan Kotagede lebih mudah dijangkau.

Tabel5. Waktu Kunjungan Wisatawan Nusantara Kotagede

Kelompok

Wisatawan

Pekerjaan

Waktu Kunjungan
Usia 18-25

Usia 26-30

Usia 31-50

\author{
Mahasiswa \\ Pegaw ai Swasta \\ Wiraswasta \\ Pegawai Swasta \\ Wiraswasta
}

\section{Sen Sel Rab Kam Jum Sab Ming}

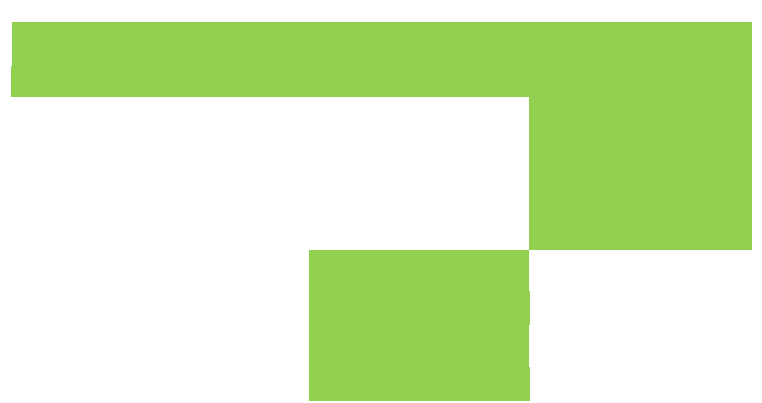

Indikator fasilitas (fasilitas umum dan pariwisata) mendapat skor yang paling rendah dibandingkan dua indikator lainnya. Hal ini dapat dimengerti karena fasilitas di kawasan wisata Kotagede belum memadai seperti: kondisi lahan parkir dikawasan Kotagede, kondisi toilet umum, dan pusat informasi yang belum memadai. 

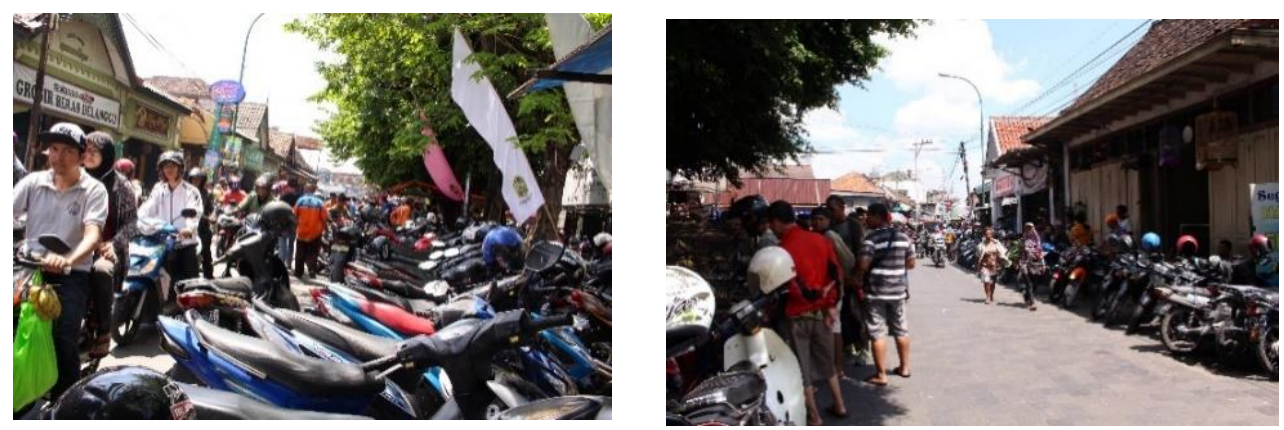

Gambar 2. Kodisi Lahan Parkir Kotagede

Sumber: Dokumen Pribadi

Tabel 6. Skor Indikator Atraksi Wis ata Berdasarkan Penilaian W isatawan

(Skala $1=$ Negatif, $2=$ agak negatif , $3=$ cukup, $4=$ positif, $5=$ sangat positif) Indikator

No

Atraksi Wisata

Item Pernyataan

1 kaw asan wisata Kotagede unik dan menarik.

2 atraksi tarik wisata budaya Kotagede unik.

3 bangunan arsitektur di Kotagede unik dan menarik.

4 masjid Mataram Kotagede menarik untuk dikunjungi.

5 kondisi lingkungan kawasan Kotagede bersih.

6 jalur wisata di kawasan Kotagede memiliki nilai tersendiri (memiliki daya tarik).

7 saya merasa aman saat melakukan aktivitas wisata di kawasan wisata kotagede.
Penilaian Wisatawan

$18-25 \quad 26-30 \quad 31-50$

tahun tahun tahun

Skala Skala Skala

$\begin{array}{lll}4,40 & 4 & 4,67\end{array}$

$\begin{array}{lll}4,30 & 4 & 4,67\end{array}$

$\mathbf{4 , 5 0} \quad 4,33 \quad 4,67$

$4,46 \quad 4,06 \quad 4,67$

$4,21 \quad 3,86 \quad 4,83$

$4,22 \quad 3,86 \quad 4,33$

$\begin{array}{lll}4,25 & 4 & 4,5\end{array}$

Berdasarkan tabel 6. di atas maka diketahui bahw a kualitas daya tarik wisata budaya Kotagede berdasarkan indikator wisata terletak pada: (1) Bangunan arsitektur Kotagede unik dan menarik dengan nilai rata-rata 4,5 (skala positif), (2) kawasan wisata Kotagede unik dan menarik dengan nilai rata-rata 4,39 (skala positif), (3) daya tarik wisata budaya Kotagede unik dengan nilai rata-rata 4,32 (skala positif), (4) keamanan saat melakukan aktivitas wisata dengan nilai rata-rata 4,25 (skala positif).

Tabel 7. Skor Indikator Aksesibilitas Berdasarkan Penilaian W isatawan

(Skala $1=$ Negatif, $2=$ agak negatif , $3=$ cukup, $4=$ positif, $5=$ sangat positif)

Indikator

No

Aksesibilitas

Item Pernyataan

1 kaw asan Kotagede mudah dijangkau
Penilaian Wisatawan

18-25 26-30 31-50

tahun tahun tahun

Skala Skala Skala

$4,15 \quad 3,93 \quad 4,5$ 
2 rambu-rambu lalu lintas menuju kawasan Kotagede mudah ditemukan.

$\begin{array}{ccc}\mathbf{3 , 8 8} & \mathbf{3 , 3 3} & \mathbf{4} \\ & & \\ \mathbf{3 , 8 8} & \mathbf{3 , 4} & 4,5 \\ & & \\ \mathbf{3 , 8 4} & \mathbf{3 , 5 3} & \mathbf{4 , 5} \\ \mathbf{4 , 1 4} & \mathbf{3 , 8} & \mathbf{4 , 5} \\ \mathbf{3 , 9 7} & \mathbf{3 , 6 6} & \mathbf{4 , 1 7} \\ \mathbf{4 , 0 3} & \mathbf{3 , 7 3} & 4 \\ \mathbf{3 , 5 2} & \mathbf{3 , 0 6} & \mathbf{3 , 1 7}\end{array}$

8 kondisi trotoar di kaw asan Kotagede baik.

Tabel 7. di atas memperlihatkan bahwa kualitas daya tarik wisata budaya Kotagede berdasarkan indikator aksesibilitas terletak pada: (1) kawasan kotagede mudah dijangkau dengan nilai rata-rata 4,19 (skala positif), (2) kondisi jalan menuju kawasan Kotagede baik dengan nilai rata-rata 4,14 (skala positif). Adapun hal yang harus diperhatikan terhadap kualitas daya tarik wisata budaya Kotagede berdasarkan indikator aksesibilitas adalah kondisi trotoar Kotagede yang nilai rata-rata 3,25 (skala cukup). Hal tersebut dikarenakan trotoar di kaw asan Kotagede dipergunakan oleh pedagang kaki lima untuk berjualan.

Tabel 8. Skor Indikator Fasilitas Berdasarkan Penilaian Wisatawan

(Skala $1=$ Negatif, $2=$ agak negatif , $3=$ cukup, $4=$ positif, $5=$ sangat positif)

$$
\text { Indikator }
$$

No

$$
\text { Fasilitas (umum dan pariwisata) }
$$

Item Pernyataan

1 pusat informasi di kawasan Kotagede tersedia dengan baik.

2 lahan parkir di kaw asan Kotagede memadai.

3 kondisi toilet umum di kawasan Kotagede memadai.

4 tempat sampah di kawasan Kotagede tersedia dengan baik.

5 toilet umum di kaw asan Kotagede mudah ditemukan.

6 informasi terkait daya tarik wisata budaya di kaw as an Kotagede mudah diperoleh.
Penilaian Wisatawan

$\begin{array}{ccc}18-25 & 26-30 & 31-50 \\ \text { tahun } & \text { tahun } & \text { tahun } \\ \text { Skala } & \text { Skala } & \text { Skala } \\ & & 4 \\ \mathbf{3 , 5 7} & \mathbf{3 , 0 6} & \mathbf{4} \\ \mathbf{3 , 7 5} & \mathbf{3} & \mathbf{4} \\ \mathbf{3 , 4 0} & \mathbf{3 , 0 6} & \mathbf{4} \\ \mathbf{3 , 8 0} & \mathbf{3 , 3 3} & \mathbf{3 , 8 3} \\ & & \\ \mathbf{3 , 5 6} & \mathbf{3 , 0 6} & \mathbf{4 , 5} \\ & & \\ \mathbf{4 , 0 9} & \mathbf{3 , 7 3} & \mathbf{4 , 5}\end{array}$

Tabel 8. di atas memperlihatkan bahwa kualitas daya tarik wisata budaya yang mendapatkan penilaian positif terhadap indikator fasilitas hanya pada kemudahan mendapatkan informasi terkait daya tarik wisata budaya di kawasan Kotagede dengan nilai rata-rata 4,1 (skala positif). Adapun hal yang harus diperhatikan terhadap kualitas daya tarik wisata budaya Kotagede berdasarkan indikator fasilitas meliputi : (1) kondisi toilet umum di kawasan Kotagede, (2) lahan parkir di kaw asan Kotagede dan, (3) pusat informasi yang belum memadai. 


\section{Minat Kunjungan Wisatawan Nusantara Kotagede}

Minat kunjungan wisatawan nusantara dikelompokkan berdasarkan jenis wisatawan yang telah diuraikan sebelumnya. Data diperoleh melalui penyebaran kuesioner terhadap 100 responden (w isataw an nusantara) dengan menggunakan dua indikator yaitu:(1) faktor penarik dan (2) faktor pendorong.

Tabe19. Skor Minat Kunjungan Wisatawan Nusantara Kotagede

\begin{tabular}{|c|c|c|c|c|c|c|c|c|}
\hline \multirow[t]{2}{*}{ Tot. Skor } & Faktor Penarik & \multicolumn{4}{|c|}{ Indikator } & \multirow[t]{2}{*}{$\begin{array}{l}\text { Jml Skor/ } \\
\text { Item }\end{array}$} & \multirow[t]{2}{*}{ Jml Item } & \multirow[t]{2}{*}{$\begin{array}{l}\text { Jml } \\
\text { Res. }\end{array}$} \\
\hline & STS & TS & RR & $\mathrm{S}$ & ST & & & \\
\hline 1 & 2 & 3 & 4 & 5 & 6 & 7 & 8 & 9 \\
\hline \multirow[t]{2}{*}{ Tot. Skor } & 12 & 83 & 279 & 2104 & 1150 & 3623 & 9 & 100 \\
\hline & \multicolumn{5}{|c|}{ Faktor Pendorong } & & & \\
\hline Tot. Skor & 3 & 36 & 123 & 892 & 575 & 1629 & 4 & 100 \\
\hline
\end{tabular}

Berdasarkan tabel 6. di atas diketahui bahwa minat kunjungan wisataw an nusantara yaitu jumlah skor ideal (kriterium) untuk seluruh item $=5 \times 13 \times 100=6.500$ (jika semua menjaw ab SS). Jumlah skor yang diperoleh dari penelitian $=5.257$. Dengan demikian, tingkat persetujuan minat kunjungan wisatawan nusantara $=(5.257: 6.500) \times 100 \%=80,87 \%$ dariyang diharapkan $(100 \%)$. Secara kontinum dapat digambarkan sebagai berikut:

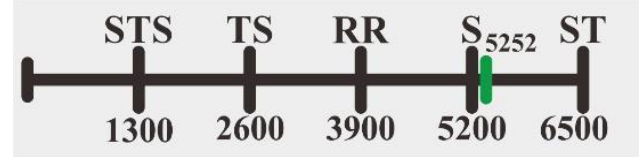

Gambar 3. Skor Minat Kunjungan W isatawan Nusantara Kotagede

Berdasarkan gambar 2. di atas data yang peroleh dari 100 responden maka rata-rata 5252 terletak pada daerah sangat setuju. Dengan demikian, minat kunjungan wisatawan nusantara Kotagede dapat dikatakan sangat tinggi.

Tabel 10. Skor Minat Kunjungan W isatawan Nus antara Kotagede

(Skala $1=$ Negatif, $2=$ agak negatif, $3=$ cukup, $4=$ positif, $5=$ sangat positif)

\section{No}

1

\section{Indikator}

2

$\begin{array}{cc}\mathbf{S} T S & \text { TS } \\ \mathbf{3} & \mathbf{4}\end{array}$

Penilaian

a. wisataw an nusantara kotagede dengan usia 18-25 tahun

1 Faktor Penarik

$$
0,24 \quad 1,35 \quad 5,80 \quad 43,09 \quad 25,51
$$

4,06

2 Faktor Pendorong

$$
\begin{array}{lllll}
0,06 & 1,39 & 5,60 & 40,55 & 28,39
\end{array}
$$

b. wisataw an nusantara kotagede dengan usia 26-30 tahun

1 Faktor Penarik

$$
\begin{array}{ccccc} 
& 0,89 & 1,653 & 9,25 & 3,095 \\
0,08 & 1,01 & 1,71 & 9,96 & 2,22
\end{array}
$$

2 Faktor Pendorong

$$
\text { , }
$$

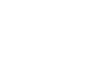

2,22

Skala

8

\section{.}


c. wisataw an nusantara kotagede dengan usia 30-50 tahun

$\begin{array}{llllrrr}1 & \text { Faktor Penarik } & 0,03 & 0,08 & 4,43 & 1,4 & \mathbf{3 , 1 2} \\ 2 & \text { Faktor Pendorong } & 0,07 & & 4,14 & 1,79 & \mathbf{4 , 1 2}\end{array}$

Tabel 10. di atas memperlihatkan bahwa skor minat kunjungan wisataw an nusantara terhadap faktor penarik mendapat nilai yang bervariasi. Skor tertinggi diberikan oleh kelompok wisataw an usia 18-25 tahun dan skor terendah diberikan oleh kelompok w isataw an usia 30-50 tahun. Hal ini semakin menguatkan bahwa profil wisatawan terkait motif kunjungan berpengaruh terhadap minat kunjungan wisataw an. Pembahasan sebelumnya memperlihatkan bahwa wisatawan usia 18-25 tahun memberikan skor yang cukup tinggi terhadap indikator atraksi wisata. Hal ini diikuti dengan memberikan skor yang positif terhadap indikator faktor penarik yang mengindikasikan bahwa motif kunjungan wisatawan untuk tujuan rekreasi lebih cenderung pada pemenuhan unsur fisik wisatawan.

Tabel 11. Skor Minat Kunjungan W isatawan Nus antara Berdasarkan Faktor Penarik

(Skala $1=$ Negatif, $2=$ agak negatif , $3=$ cukup, $4=$ positif, $5=$ sangat positif)

$$
\text { Indikator }
$$

No

Faktor Penarik

Item Pernyataan

informasi yang lengkap tentang kawasan wisata

1 Kotagede menjadi faktor utama bagi saya untuk berkunjung.

kondisi jalan yang baik menuju kawasan wisata

2 Kotagede menjadi salah satu faktor penting bagi saya untuk berkunjung.

fasilitas umum dan fasilitas pariwisata yang lengkap

3 menjadi salah satu faktor penting bagi saya untuk berkunjung ke Kotagede.

4 kemudahan dalam berwisata menjadi alasan bagi saya untuk mengujungi Kotagede.

keunikan kawasan wisata Kotagede menjadi alasan bagi saya untuk berkunjung.

6 keragaman daya tarik wisata budaya Kotagede menjadi alasan bagi saya untuk berkunjung.

7 bangunan arsitektur di Kotagede menarik untuk dikunjungi.

8

bangunan arsitektur di Kotagede memiliki nilai tersendiri bagi saya.

kondisi tempat parkir dan toilet umum yang

9 memadai sangat penting dalam menunjang aktivitas wisata saya di Kotagede.
Penilaian Wisatawan

$18-25 \quad 26-30 \quad 31-50$

tahun tahun tahun

Skala Skala Skala

$3,75 \quad 3,6 \quad 3,83$

$\begin{array}{lll}4,02 & 3,73 & 4\end{array}$

$3,86 \quad 3,53 \quad 4,16$

4,10 3,86 $\quad 3,66$

$4,14 \quad 4,06 \quad 3,66$

$4,13 \quad 4,06 \quad 4,16$

$4,31 \quad 4,06 \quad 4,16$

$4,28 \quad 4,13 \quad 4,16$

$3,96 \quad 3,46 \quad 4,16$

Tabel 11. di atas memperlihatkan bahwa minat kunjungan wisataw an nusantara ke Kotagede berdasarkan faktor penarik dipengaruhi oleh (1) nilai dari bangunan arsitektur 
Kotagede terhadap kunjungan wisataw an (nilai rata-rata 4,19 atau mendapat skala positif), (2) keragaman daya wisata budaya Kotagede (nilai rata-rata 4,11 skala positif).

Tabel 5.12. Skor Minat Kunjungan W isatawan Nusantara Berdasarkan Faktor Pendorong (Skala $1=$ Negatif, $2=$ agak negatif , $3=$ cukup, $4=$ positif, $5=$ sangat positif)

$$
\text { Indikator }
$$

No

Faktor Pendorong

Item Pernyataan

1

biaya menjadi salah satu faktor penting bagi saya

dalam berkunjung ke Kotagede.

2 biaya perjalanan ke Kotagede murah

3

waktu menjadi salah satu faktor penting bagi saya

untuk mengunjungi Kotagede.

4

waw asan saya bertambah setelah saya mengunjungi

daya tarik wisata budaya di Kotagede.
Penilaian Wisatawan

18-25 26-30 31-50

tahun tahun tahun

Skala Skala Skala

$3,85 \quad 3,13 \quad 4,16$

$4,43 \quad 3,93 \quad 3,66$

$4,05 \quad 3,66 \quad 4,33$

$4,1 \quad 4,06 \quad 4,33$

Minat kunjungan wisatawan nusantara berdasarkan faktor pendorong lebih dipengaruhi oleh: (1) bertambahnya wawasan wisataw an setelah mengunjungi daya tarik wisata budaya Kotagede dengan nilai rata-rata 4,16 (skala positif), dan (2) unsur waktu berkunjung menjadi penting bagi wisatawan dengan nilai 4,01 (skala positif). Adapun hal yang menarik ialah terkait pernyataan wisatawan yang mengatakan bahwa biaya perjalanan ke Kotagede murah. Akan tetapi bukan merupakan faktor penting dalam berkunjung ke Kotagede.

\section{Uji Validitas Instrumen}

Tabel 13. Hasil uji validitas instrumen penelitian variabel $(\mathrm{X})$ kualitas daya tarik wis ata budaya

$\begin{array}{ccccc}\begin{array}{c}\text { No. Butir } \\ \text { Instrumen }\end{array} & \begin{array}{c}\mathrm{r} \\ \text { Hitung }\end{array} & \begin{array}{c}\mathrm{r} \text { Product Moment }(\mathrm{r} \text { tabel, } \\ \text { taraf signifikan 5\%) }\end{array} & \text { Validitas } & \text { Indikator } \\ \text { Item-1 } & 0,635 & 0,361 & \text { Valid } & \\ \text { Item-2 } & 0,665 & 0,361 & \text { Valid } & \\ \text { Item-3 } & 0,613 & 0,361 & \text { Valid } & \\ \text { Item-4 } & 0,638 & 0,361 & \text { Valid } & \text { Atraksi Wisata } \\ \text { Item-5 } & 0,759 & 0,361 & \text { Valid } & \\ \text { Item-6 } & 0,388 & 0,361 & \text { Valid } & \\ \text { Item-7 } & 0,635 & 0,361 & \text { Valid } & \\ \text { Item-8 } & 0,688 & 0,361 & \text { Valid } & \\ \text { Item-9 } & 0,594 & 0,361 & \text { Valid } & \\ \text { Item-10 } & 0,609 & 0,361 & \text { Valid } & \text { Aksesibilitas } \\ \text { Item-11 } & 0,535 & 0,361 & \text { Valid } & \\ \text { Item-12 } & 0,573 & 0,361 & \text { Valid } & \end{array}$




$\begin{array}{ccccc}\text { Item-13 } & 0,408 & 0,361 & \text { Valid } & \\ \text { Item-14 } & 0,493 & 0,361 & \text { Valid } & \text { Valid } \\ \text { Item-15 } & 0,362 & 0,361 & \text { Tidak valid } & \\ \text { Item-16 } & 0,172 & 0,361 & \text { Tidak valid } & \\ \text { Item-17 } & 0,196 & 0,361 & \text { Tidak valid } & \\ \text { Item-18 } & 0,267 & 0,361 & \text { Valid } & \\ \text { Item-19 } & 0,669 & 0,361 & \text { Valid } & \text { Fasilitas } \\ \text { Item-20 } & 0,856 & 0,361 & \text { Valid } & \\ \text { Item-21 } & 0,825 & 0,361 & \text { Valid } & \\ \text { Item-22 } & 0,813 & 0,361 & \text { Valid } & \\ \text { Item-23 } & 0,828 & 0,361 & \text { Valid } & \\ \text { Item-24 } & 0,444 & 0,361 & \text { ar } & \end{array}$

Berdasarkan tabel 13. di atas diketahui, bahw a butir no 16, 17 (indikator aksesibilitas) dan no 18 (indikator fasilitas) tidak valid, karena korelasi dengan skor total hanya 0,173 dan 0,19 (di bawah $r$ tabel 0,361) serta 0,26 (di bawah $r$ tabel 0,361). Untuk itu maka butir-butir tersebut dikeluarkan dari item yang telah ditetapkan dalam kuesioner penelitian.

Tabel 14. Hasil uji validitas instrumen penelitian variabel $(\mathrm{Y})$ minat kunjungan wis atawan nusantara

$\begin{array}{ccccc}\begin{array}{c}\text { No. Butir } \\ \text { Instrumen }\end{array} & \begin{array}{c}\mathrm{r} \\ \text { Hitung }\end{array} & \begin{array}{c}\mathrm{r} \text { Product Moment }(\mathrm{r} \text { tabel, } \\ \text { taraf signifikan } 5 \%)\end{array} & \text { Validitas } & \text { Indikator } \\ \text { Item-1 } & 0,656 & 0,361 & \text { Valid } & \\ \text { Item-2 } & 0,589 & 0,361 & \text { Valid } & \\ \text { Item-3 } & 0,691 & 0,361 & \text { Valid } & \\ \text { Item-4 } & 0,595 & 0,361 & \text { Valid } & \\ \text { Item-5 } & 0,665 & 0,361 & \text { Valid } & \text { Faktor Penarik } \\ \text { Item-6 } & 0,409 & 0,361 & \text { Valid } & \\ \text { Item-7 } & 0,568 & 0,361 & \text { Valid } & \\ \text { Item-8 } & 0,379 & 0,361 & \text { Valid } & \\ \text { Item-9 } & 0,562 & 0,361 & \text { Valid } & \\ \text { Item-10 } & 0,768 & 0,361 & \text { Valid } & \\ \text { Item-11 } & 0,499 & 0,361 & \text { Valid } & \text { Faktor } \\ \text { Item-12 } & 0,571 & 0,361 & \text { Valid } & \text { Pendorong } \\ \text { Item-13 } & 0,522 & 0,361 & \text { Valid } & \end{array}$


Berdasarkan tabel 14. di atas diketahui bahwa butir-butir yang berada dalam tabel tersebut valid karena $r$ hitung dari tiap item di atas $r$ tabel. Untuk itu item-item dengan nilai yang valid akan dimasukkan sebagai item dalam kuesioner penelitian. Maka kuesioner dengan item tersebut akan dijadikan sebagi instrumen dalam penelitian, dan akan digunakan untuk pengambilan data terkait kualitas daya tarik wisata budaya, minat kunjungan wisatawan nusantara dan kepentingan analisis terhadap pengaruh kedua variabel yang telah disebutkan sebelumnya.

\section{Pengujian Hipotesis}

Uji hipotesis dilakukan untuk membuktikan apakah terdapat pengaruh yang positif antara kualitas daya tarik wisata budaya terhadap minat kunjungan wisataw an nusantara ke Kotagede?.

Tabel 15. Rangkuman Data Kualitas Daya Tarik W is ata Budaya dan Minat Kunjungan Wisatawan Nusantara

\begin{tabular}{|c|c|c|c|c|c|c|c|c|c|c|c|}
\hline $\begin{array}{l}\text { No } \\
\text { Res }\end{array}$ & $x$ & $y$ & $\left(x^{2}\right)$ & $\left(y^{2}\right)$ & $(x y)$ & $\begin{array}{l}\text { No } \\
\text { Res }\end{array}$ & $x$ & $y$ & $\left(x^{2}\right)$ & $\left(y^{2}\right)$ & $(x y)$ \\
\hline 1 & 5,04 & 1,48 & 25,4016 & 2,1904 & 7,4592 & 51 & 4,04 & 9,48 & 16,3216 & 89,8704 & 38,2992 \\
\hline 2 & 19,04 & 12,52 & 362,522 & 156,7504 & $-238,38$ & 52 & $-3,96$ & $-2,52$ & 15,6816 & 6,3504 & 9,9792 \\
\hline 3 & 9,04 & $-0,52$ & 81,7216 & 0,2704 & $-4,7008$ & 53 & 9,04 & $-1,52$ & 81,7216 & 2,3104 & $-13,741$ \\
\hline 4 & 0,04 & $-0,52$ & 0,0016 & 0,2704 & $-0,0208$ & 54 & $-8,96$ & $-8,52$ & 80,2816 & 72,5904 & 76,3392 \\
\hline 5 & 14,04 & 6,48 & 197,122 & 41,9904 & 90,9792 & 55 & 7,04 & $-0,52$ & 49,5616 & 0,2704 & $-3,6608$ \\
\hline 6 & $-0,96$ & $-0,52$ & 0,9216 & 0,2704 & 0,4992 & 56 & 15,04 & 5,48 & 226,202 & 30,0304 & 82,4192 \\
\hline 7 & 11,04 & 3,48 & 121,882 & 12,1104 & 38,4192 & 57 & $-1,96$ & 7,48 & 3,8416 & 55,9504 & $-14,661$ \\
\hline 8 & $-1,96$ & $-2,52$ & 3,8416 & 6,3504 & 4,9392 & 58 & ${ }^{-}$ & $-2,52$ & 120,122 & 6,3504 & 27,6192 \\
\hline 9 & $\begin{array}{c}- \\
17,96\end{array}$ & 10,52 & 322,562 & 110,6704 & 188,939 & 59 & 10,96 & $-5,52$ & 120,122 & 30,4704 & 60,4992 \\
\hline 10 & 3,04 & $-1,52$ & 9,2416 & 2,3104 & $-4,6208$ & 60 & 7,04 & $-6,52$ & 49,5616 & 42,5104 & $-45,901$ \\
\hline 11 & $-3,96$ & 13,52 & 15,6816 & 182,7904 & 53,5392 & 61 & 10,96 & 3,48 & 120,122 & 12,1104 & $-38,141$ \\
\hline 12 & 3,04 & $-3,52$ & 9,2416 & 12,3904 & $-10,701$ & 62 & 7,04 & 9,48 & 49,5616 & 89,8704 & 66,7392 \\
\hline 13 & 0,04 & $-2,52$ & 0,0016 & 6,3504 & $-0,1008$ & 63 & $-0,96$ & $-2,52$ & 0,9216 & 6,3504 & 2,4192 \\
\hline 14 & $-2,96$ & $-1,52$ & 8,7616 & 2,3104 & 4,4992 & 64 & 11,04 & 7,48 & 121,882 & 55,9504 & 82,5792 \\
\hline 15 & 24,04 & 12,48 & 577,922 & 155,7504 & 300,019 & 65 & $-2,96$ & 7,48 & 8,7616 & 55,9504 & $-22,141$ \\
\hline 16 & $-6,96$ & 12,52 & 48,4416 & 156,7504 & 87,1392 & 66 & $-8,96$ & $-2,52$ & 80,2816 & 6,3504 & 22,5792 \\
\hline 17 & $-3,96$ & $-2,52$ & 15,6816 & 6,3504 & 9,9792 & 67 & $-2,96$ & $-6,52$ & 8,7616 & 42,5104 & 19,2992 \\
\hline 18 & 2,04 & 0,48 & 4,1616 & 0,2304 & 0,9792 & 68 & 0,04 & $-0,52$ & 0,0016 & 0,2704 & $-0,0208$ \\
\hline 19 & 9,04 & 4,48 & 81,7216 & 20,0704 & 40,4992 & 69 & $-4,96$ & 6,48 & 24,6016 & 41,9904 & $-32,141$ \\
\hline 20 & 7,04 & 4,48 & 49,5616 & 20,0704 & 31,5392 & 70 & $-6,96$ & $-0,52$ & 48,4416 & 0,2704 & 3,6192 \\
\hline 21 & 3,04 & $-2,52$ & 9,2416 & 6,3504 & $-7,6608$ & 71 & 12,96 & 2,48 & 167,962 & 6,1504 & $-32,141$ \\
\hline 22 & $-6,96$ & $-2,52$ & 48,4416 & 6,3504 & 17,5392 & 72 & $-7,96$ & 0,48 & 63,3616 & 0,2304 & $-3,8208$ \\
\hline
\end{tabular}




\begin{tabular}{|c|c|c|c|c|c|c|c|c|c|c|c|}
\hline 23 & $-0,96$ & 1,48 & 0,9216 & 2,1904 & $-1,4208$ & 73 & $\overline{14,96}$ & $\stackrel{-}{16,52}$ & 223,802 & 272,9104 & 247,139 \\
\hline 24 & 8,04 & $-0,52$ & 64,6416 & 0,2704 & $-4,1808$ & 74 & 1,04 & $-0,52$ & 1,0816 & 0,2704 & $-0,5408$ \\
\hline 25 & $-4,96$ & 1,48 & 24,6016 & 2,1904 & $-7,3408$ & 75 & 17,04 & $-2,52$ & 290,362 & 6,3504 & $-42,941$ \\
\hline 26 & $-3,96$ & 0,48 & 15,6816 & 0,2304 & $-1,9008$ & 76 & $-2,96$ & $-1,52$ & 8,7616 & 2,3104 & 4,4992 \\
\hline 27 & $-6,96$ & 4,48 & 48,4416 & 20,0704 & $-31,181$ & 77 & $-0,96$ & 7,48 & 0,9216 & 55,9504 & $-7,1808$ \\
\hline 28 & 20,04 & 11,48 & 401,602 & 131,7904 & 230,059 & 78 & $-5,96$ & $-1,52$ & 35,5216 & 2,3104 & 9,0592 \\
\hline 29 & 4,04 & 5,48 & 16,3216 & 30,0304 & 22,1392 & 79 & $-6,96$ & $-3,52$ & 48,4416 & 12,3904 & 24,4992 \\
\hline 30 & 8,04 & 6,48 & 64,6416 & 41,9904 & 52,0992 & 80 & 0,04 & 3,48 & 0,0016 & 12,1104 & 0,1392 \\
\hline 31 & 12,04 & 6,48 & 144,962 & 41,9904 & 78,0192 & 81 & 3,04 & $-1,52$ & 9,2416 & 2,3104 & $-4,6208$ \\
\hline 32 & 10,04 & 5,48 & 100,802 & 30,0304 & 55,0192 & 82 & 2,04 & 0,48 & 4,1616 & 0,2304 & 0,9792 \\
\hline 33 & 0,04 & 6,48 & 0,0016 & 41,9904 & 0,2592 & 83 & 1,04 & 7,48 & 1,0816 & 55,9504 & 7,7792 \\
\hline 34 & $\begin{array}{c}- \\
11,96\end{array}$ & 1,48 & 143,042 & 2,1904 & $-17,701$ & 84 & 18,04 & 11,48 & 325,442 & 131,7904 & 207,099 \\
\hline 35 & $\begin{array}{c}- \\
20,96\end{array}$ & $-9,52$ & 439,322 & 90,6304 & 199,539 & 85 & 6,04 & 0,48 & 36,4816 & 0,2304 & 2,8992 \\
\hline 36 & $-9,96$ & 0,48 & 99,2016 & 0,2304 & $-4,7808$ & 86 & 13,04 & 6,48 & 170,042 & 41,9904 & 84,4992 \\
\hline 37 & 4,04 & $-2,52$ & 16,3216 & 6,3504 & $-10,181$ & 87 & 5,04 & 6,48 & 25,4016 & 41,9904 & 32,6592 \\
\hline 38 & $-6,96$ & $-4,52$ & 48,4416 & 20,4304 & 31,4592 & 88 & $\begin{array}{c}- \\
10,96\end{array}$ & $-1,52$ & 120,122 & 2,3104 & 16,6592 \\
\hline 39 & $-4,96$ & $-4,52$ & 24,6016 & 20,4304 & 22,4192 & 89 & $-3,96$ & 0,48 & 15,6816 & 0,2304 & $-1,9008$ \\
\hline 40 & 11,04 & 5,48 & 121,882 & 30,0304 & 60,4992 & 90 & 12,96 & - & 167,962 & 132,7104 & 149,299 \\
\hline 41 & $\begin{array}{c}- \\
10,96\end{array}$ & $-9,52$ & 120,122 & 90,6304 & 104,339 & 91 & $-2,96$ & 6,48 & 8,7616 & 41,9904 & $-19,181$ \\
\hline 42 & $-1,96$ & $-0,52$ & 3,8416 & 0,2704 & 1,0192 & 92 & 0,04 & $-2,52$ & 0,0016 & 6,3504 & $-0,1008$ \\
\hline 43 & $-1,96$ & $-7,52$ & 3,8416 & 56,5504 & 14,7392 & 93 & $-1,96$ & 3,48 & 3,8416 & 12,1104 & $-6,8208$ \\
\hline 44 & 0,04 & $-0,52$ & 0,0016 & 0,2704 & $-0,0208$ & 94 & 9,04 & $-0,52$ & 81,7216 & 0,2704 & $-4,7008$ \\
\hline 45 & 8,04 & 6,48 & 64,6416 & 41,9904 & 52,0992 & 95 & 0,04 & $-2,52$ & 0,0016 & 6,3504 & $-0,1008$ \\
\hline 46 & $-4,96$ & $-3,52$ & 24,6016 & 12,3904 & 17,4592 & 96 & $-2,96$ & 8,48 & 8,7616 & 71,9104 & $-25,101$ \\
\hline 47 & 9,04 & 3,48 & 81,7216 & 12,1104 & 31,4592 & 97 & 2,04 & 0,48 & 4,1616 & 0,2304 & 0,9792 \\
\hline 48 & $-7,96$ & $-1,52$ & 63,3616 & 2,3104 & 12,0992 & 98 & $-4,96$ & $-3,52$ & 24,6016 & 12,3904 & 17,4592 \\
\hline 49 & $\begin{array}{c}- \\
18,96\end{array}$ & $\begin{array}{c}- \\
10,52\end{array}$ & 359,482 & 110,6704 & 199,459 & 99 & 0,04 & $-2,52$ & 0,0016 & 6,3504 & $-0,1008$ \\
\hline 50 & $-8,96$ & $-5,52$ & 80,2816 & 30,4704 & 49,4592 & 100 & 0,04 & $-0,52$ & 0,0016 & 0,2704 & $-0,0208$ \\
\hline & & & & & & $\sum$ & & & 7645,84 & 3366,96 & 2744,08 \\
\hline
\end{tabular}




\section{Uji Person Product Moment}

diketahui: $\left(1 \cdot \sum \mathrm{X}=8096,2 \cdot \sum \mathrm{Y}=5252,3 . \quad \sum \mathrm{x}^{2}=7645,84,4 \cdot \sum \mathrm{y}^{2}=3366,96,5 \cdot \sum \mathrm{xy}=\right.$ 2744,08). Nilai-nilai tersebut digunakan untuk melakukan perhitungan sebagai berikut:

$$
\mathbf{r}_{\mathrm{xy}}=\frac{\sum \mathrm{xy}}{\sqrt{\left(\sum \mathrm{x}^{2}\right)\left(\sum \mathbf{y}^{2}\right)}}=\frac{2744,08}{\sqrt{\mathbf{7 6 5 4}, 84 \times 3366,96}}=\mathbf{0 , 5 4 0}
$$

Maka $r_{\text {hitung }}=0,54084$ dibulatkan menjadi $r_{\text {hitung }}=0,540$ sedangkan $r_{\text {tabel }}=0,195(n$ $=100$ pada interval kepercayaan 95\% atau dengan tingkat kesalahan 5\%). Dengan demikian $\mathrm{r}_{\text {hitung }}>\mathrm{r}_{\text {tabel }}$ atau 0,540 $>0,195$ dan Ha diterima.

\section{Uji t-test}

$$
t=\frac{r \sqrt{n}-2}{\sqrt{1}-r^{2}}=\frac{0,540 \sqrt{100}-2}{\sqrt{1}-0,540^{2}}=6,356
$$

$\mathrm{t}_{\text {tabel }}$ pada taraf signifikan 5\% dengan $23 \mathrm{r}=100-2=98$ yaitu 1,661 . Maka, $\mathrm{t}_{\text {test }}>\mathrm{t}_{\text {tabel }}$ atau 6,356 >1,661. Berdasarkan perhitungan di atas maka dapat dinyatakan bahwa pengaruh antara kualitas daya tarik wisata budaya dan minat kunjungan wisatawan sebesar 0,540 adalah signifikan sehingga digeneralisasikan untuk populasi di mana diambil (Ho: tidak ada pengaruh ditolak).

\section{KESIMPULAN}

Berdasarkan hasil pembahasan maka dapat disimpulkan bahwa: 1. Kualitas daya tarik wisata budaya Kotagede memiliki nilai yang baik dengan unsur-unsur kualitas daya tarik wisata budaya Kotagede terletak pada: (a) keunikan bangunan arsitektur dan kawasan Kotagede (b) keberagaman daya tarik wisata budaya Kotagede (c) kondisi lingkungan Kotagede yang bersih 2. Minat kunjungan wisatawan nusantara ke Kotagede sangat tinggi. Minat kunjungan wisatawan nusantara ke Kotagede lebih dipengaruhi oleh faktor penarik yaitu faktor-faktor yang berasal dari dalam daya tarik w is ata budaya Kotagede sendiri yang meliputi keunikan dan keberagaman. 3. Berdasarkan hasil uji coba person product moment dan hasil uji $t$-test, maka diketahui bahwa terdapat pengaruh positif antara kualitas daya tarik budaya terhadap minat kunjungan wisataw an nusantara ke Kotagede dengan $r_{h i t u n g}=0,540$. Dengan demikian $r_{h i t u n g}>$ $r_{\text {tabel }}$ atau 0,540 > 0,195 dan Ha diterima artinya terdapat pengaruh yang positif antara kualitas daya tarik wisata budaya terhadap minat kunjungan wisatawan nusantara ke Kotagede.

\section{Ucapan terima kasih}

1. Ibu Dr. Ir. Dwi Hadi Rahmi, M.A selaku dosen pembimbing utama yang telah memberikan arahan, masukan, gagasan, nasihat serta waktu demi kesempurnaan tesis ini.

2. Bapak Ir. Ikaputra, M.Eng. P.hD. selaku Ketua Program Magister Teknik Arsitektur Universitas Gadjah Mada Yogyakarta

3. Bapak-Ibu Dosen Magister Arsitektur Konsentrasi Arsitektur Pariwisata yang tidak dapat disebutkan satu per satu yang telah memberikan ilmu selama proses perkuliahan

4. Bapak dan Ibu Administrasi Magister Arsitektur Konsentrasi Arsitektur Pariwisata yang telah bersedia membantu dalam proses perkuliahan sampai selesai studi saya

5. Keluarga dan teman-teman yang tidak dapat disebutkan satu persatu yang telah memberikan masukan yang baik kepada penulis selama penulisan tesis ini

6. Seluruh responden yang telah meluangkan w aktunya untuk bersedia menjaw ab kuesioner penelitian ini. 


\section{DAFTAR PUSTAKA}

Adhelia, Ahjono dan Yudana. 2015. "Persepsi Wisatawan Lokal Terhadap Terhadap Citra Kotagede Sebagai Destinasi Wisata. Region," 6 : 14-18.

Bobby Citra Octaviano. 2013. "Kualitas Produk Wisata Arsitektural di Kawasan Kotagede, Yogyakarta," Teknik Arsitektur. Universitas Gadjah Mada. Yogyakarta.

Foster, Douglas. 1985. Travel and Tourism Managemen, London: Macmillan Press LTD

Iswati,Tri Yuni. 2009. Kampung Dalem Dibalik Kemegahan Kotagede. Surakarta: Sebelas Maret Universitas Press

Marhendi, Mengku. 2005. Manajemen Wisata. Semarang: Universitas Katholic Soengijapranata

Pitana, I Gde, dan I Ketut Surya Diarta. 2009. Pengantar Ilmu Pariwisata. Yogyakarta : Andi Offset

Pitana, I Gde, dan Putu G. Gayatri. 2005. Sosiologi Pariwisata. Yogyakarta: Andi Offset

Pendit, Nyoman.S. 2006. Ilmu Pariwisata Sebuah Pengantar Perndana. Edisi Terbaru. Jakarta: Pradya Paramita

Sammeng, Andi Mappi. 2001. Cakrawala Pariwisata. Jakarta. Balai Pustaka

Soekadijo. 1996. Anatomi Pariwisata. Jakarta : Gramedia Pustaka Utama

Spillane, James. 1997. Pariw isata Indonesia. Yogyakartya : Kanisius

Yogyakarta

, Statistik Kepariw is ataan 2016. Yogyakarta : Dinas Pariwisata Daerah Istimewa

Sugiyono. 2014. Metode Penelitian Kuantitatif Kualitatif dan R\&D. 2014. Bandung: Alfabeta

Yoeti ,Oka A. 2016. Perencanaan \& Pengembangan Pariwisata, Jakarta : Balai Pustaka.

, 2002. Perencanaan Strategi Pemasaran Daerah Tujuan Wisata. Jakarta.

Daerah Tujuan Wisata. Jakarta. 